\title{
СВОБОДНОРАДИКАЛЬНОЕ ОКИСЛЕНИЕ И АНТИОКСИДАНТНЫЙ СТАТУС У ЖИВОТНЫХ ПОД ДЕЙСТВИЕМ МАЛЫХ ДОЗ ГЕРБИЦИДА \\ 2,4-ДИХЛОРФЕНОКСИУКСУСНОЙ киСлОты
}

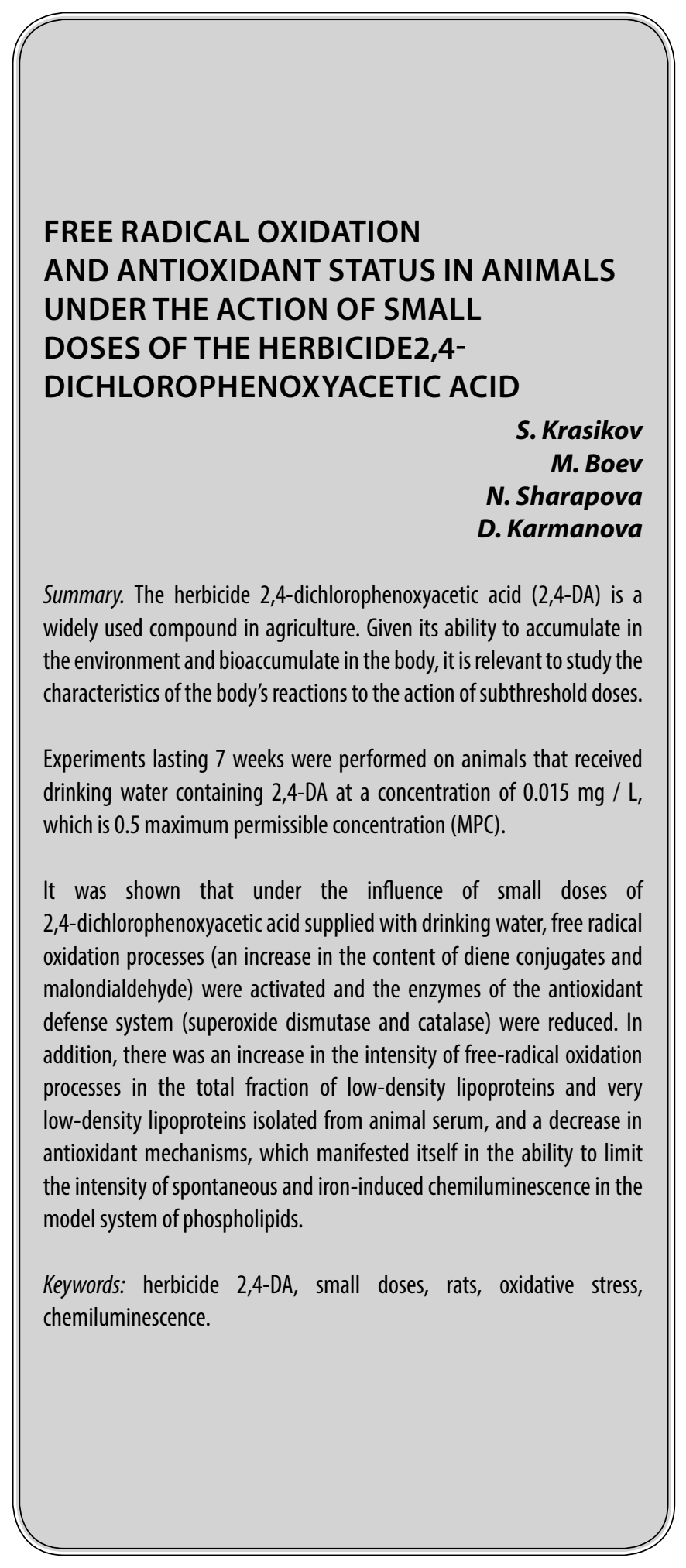

Красиков Сергей Иванович

Д.м.н., профессор, ФГБОУ ВО Оренбургский государственный медицинский университет Минздрава

России (2. Оренбург)

ks_oren@mail.ru

Боев Михаил Викторович

Д.м.н., професссор, ФГБОУВО Оренбургский государственный медицинский университет Минздрава

России (2. Оренбург)

boevm@inbox.ru

Шарапова Наталия Васильевна

К.б.н., доцент, ФГБОУ ВО Оренбургский государственный медицинский университет Минздрава

России (2. Оренбург)

natalya.sharapova2010@yandex.ru

Карманова Дарья Сергеевна

Старший преподаватель, ФГБОУ ВО Оренбургский государственный медицинский университет Минздрава

России (2. Оренбург)

daryakarmanova@mail.ru

Аннотация. Гербицид 2,4-дихлорфеноксиуксусной кислоты (2,4-ДА) относится к широко применяемому соединению в сельском хозяйстве. Учитывая его способность к аккумуляции в среде обитания и биоаккумуляции в организме, представляет актуальность исследования особенностей реакций организма на действие подпороговых доз.

Эксперименты, длительностью 7 недель, проводились на животных, которые получали питьевую воду, содержащую 2,4-ДА в концентрации 0,015 мг/л, что составляет 0,5 предельно допустимую концентрацию (ПДК).

Показано, что под влиянием малых доз 2,4-дихлорфеноксиуксусной кислоты, поступающей с питьевой водой, происходила активация процессов свободно-радикального окисления (повышение содержания диеновых конъюгатов и малонового диальдегида) и снижение мощности ферментов системы антиоксидантной защиты (супероксиддисмутазы и каталазы). Кроме того, отмечалось повышение интенсивности процессов свободно-радикального окисления в суммарной фракции липопротеинов низкой плотности и липопротеинов очень низкой плотности, выделенной из сыворотки животных, и снижение антиоксидантных механизмов, которое проявлялось в способности ограничивать интенсивность спонтанной и железоиндуцированной хемилюминесценции в модельной системе фосфолипидов.

Ключевые слова: гербицид 2,4-ДА, малые дозы, крысы, окислительный стресс, хемилюминесценция. 


\section{Введение}

$\longrightarrow$ учетом высокой ценности питьевой воды для человека, значительно возрастает роль мер, направленных на снижение загрязнения источников питьевого водоснабжения вредными химическими веществами [16, с. 1685; 1]. Одними из достаточно распространенных загрязнителей воды являются пестициды, в частности хлорорганический гербицид 2,4-дихлорфеноксиуксусной кислоты (2,4-ДА), занимающий первое место по скорости всасывания и проникновения через биологические мембраны, а также кумулятивной способности, и широко применяемый в сельском хозяйстве [8, с. 1532; 9, с. 780]. Ранее показано, что поступление с питьевой водой в организм нетоксичных доз гербицида 2,4-ДА, оказывает неблагоприятное воздействие [12, с. 4480]. В то же время недостаточно изучены механизмы, через которые пестициды реализуют свои неблагоприятные эффекты при поступлении с питьевой водой в малых концентрациях. В связи с особенностями метаболизма 2,4-ДА, происходящего в микросомах печени при участии цитохрохома Р450, с образованием активных форм кислорода, можно предположить, что и малые дозы также будут подвергаться метаболизму с образованием активных форм кислорода [13, с. 25], что в свою очередь будет приводить к развитию окислительного стресса. Учитывая роль окислительного стресса в развитии широкого спектра заболеваний [15, с. 530], можно предположить, что существует зависимость между содержанием малых доз 2,4-ДА в питьевой воде и их прооксидантной активностью. Однако данный вопрос требует изучения, и, в первую очередь, экспериментального подтверждения, что и послужило целью настоящей работы.

\section{Материалы и метолы}

Работа выполнена на 42 крысах самцах линии Вистар. Животные содержались в виварии с соблюдением циклов день/ночь - 12:12 и на сбалансированной диете (гранулированный корм для лабораторных животных «ПроКорм», Компания БиоПро) для питья животным давали бутилированную воду из местного артезианского источника. В течение всего эксперимента животным был обеспечен неограниченный доступ к воде и пище. Все животные были разделены на две группы. Животные первой группы служили контролем. У животных второй группы питьевая вода содержала 2,4-ДА в концентрации 0,015 мг/л, что соответствует 0,5 ПДК. Продолжительность эксперимента составила 7 недель, после чего животных с соблюдением этических норм и правил работы с лабораторными животными выводили из эксперимента, подвергая эвтаназии путем декапитации. Кровь и внутренние органы забирались и использовались для биохимических исследований. В сыворотке крови, полученной после центрифугирования при 3000 об/мин, определяли содержание диеновых коньюгатов (ДК) по методу Z. Placer [18, с. 670], малонового диальдегида по реакции с тиобарбитуровой кислотой [17, с. 355] на спектрофотометре «Genesys 5» (USA). Определение активности супероксиддисмутазы (СОД) в эритроцитах крови осуществлялось спектрофотометрически, методика основана на ингибировании реакции автоокисления адреналина [5, с. 270]. Определение активности каталазы проводили кинетическим спектрофотометрическим методом прямой регистрации разложения субстрата фермента - перекиси водорода [19, с. 890]. Внутренние органы - печень, сердце, селезенка измельчали с помощью гомогенизатора (Heidolph SilentCrusher M) в 0,15 M трис-HCl буфера $(\mathrm{pH}=7,4)$ в соотношении $1 / 10$ и не разрушающим ткани и ядра клеток осаждением при $500 \mathrm{~g}$. В полученных супернатантах определяли содержание продуктов перекисного окисления липидов (ПОЛ) и активность антиоксидантных ферментов по тем же, что и в сыворотке крови методам.

Измерение интенсивности хемилюминесценции (ХЛ) суммарной фракции липопротеинов низкой плотности (ЛПНП) и липопротеинов очень низкой плотности (ЛПОНП) сыворотки крови проводили по методике Ю.М. Лопухина, Ю.А. Владимирова и др. (1983). Наиболее информативными показателями, описывающими интенсивность спонтанной и железоиндуцированной хемилюминесценции в исследуемом материале, являются спонтанная светимость, величина быстрой вспышки, светосумма медленной вспышки. Спонтанная светимость (СПС) характеризует интенсивность свободно-радикального окисления (СРО) в нативной сыворотке, в неактивированной сыворотке или отдельной липидной фракции. Быстрая вспышка (h), возникающая в ответ на введение в систему активатора $\mathrm{Fe}^{2+}$, максимальное значение $\mathrm{h}$ пропорционально содержанию в исследуемом материале гидроперекисей, в том числе и гидроперекисей липидов. Светосумма медленной вспышки (S), третий из оцениваемых показателей, носит прямую зависимость от числа боковых цепей окисления, т.е. ей соответствует максимальная интенсивность (скорость) $\mathrm{CPO}$, возникающая в системе после введения $\mathrm{Fe}^{2+}[6$, C. $80 ; 2$, c. 61$]$.

Исследование антиоксидантной активности сыворотки крови изучали в соответствии с методиками, предложенными Г.И. Клебановым, Ю.А. Владимировым и др. (1988), и Р.Р. Фархутдиновым (2005). В качестве модельной системы использовали суспензию липопротеинов желтка куриных яиц [7, с. 20]. ХЛ измеряли прибором хемилюминомером (ХЛМ - 003).

Полученные результаты проводимых исследований обрабатывали методами параметрической статистики 
Таблица 1. Влияние малых доз гербицида 2,4-дихлорфеноксиуксусной кислоты на содержание продуктов ПОЛ у животных, $(\mathrm{M} \pm \mathrm{m})$

\begin{tabular}{|c|c|c|c|c|c|c|}
\hline \multirow[b]{2}{*}{ Группа, число крыс } & \multicolumn{2}{|c|}{ Сыворотка крови } & \multicolumn{2}{|l|}{ Печень } & \multicolumn{2}{|l|}{ Сердце } \\
\hline & $\begin{array}{l}\text { ДК, } \\
\text { Ед.опт.пл./л }\end{array}$ & $\begin{array}{l}\text { МДА, } \\
\text { ммоль/л }\end{array}$ & $\begin{array}{l}\text { ДК, Ед.опт.пл./ } \\
\text { кг белка }\end{array}$ & $\begin{array}{l}\text { МДА, нмоль/ } \\
\text { г белка }\end{array}$ & $\begin{array}{l}\text { ДК, Ед.опт. } \\
\text { пл./ } \\
\text { кг белка }\end{array}$ & $\begin{array}{l}\text { МДА, } \\
\text { нмоль/ } \\
\text { г белка }\end{array}$ \\
\hline $\begin{array}{l}1 \text { - Контроль } \\
\mathrm{n}=22\end{array}$ & $\begin{array}{l}0,65 \pm \\
0,04\end{array}$ & $\begin{array}{l}43,3 \pm \\
4,9\end{array}$ & $\begin{array}{l}0,46 \pm \\
0,04\end{array}$ & $\begin{array}{l}0,32 \pm \\
0,03\end{array}$ & $\begin{array}{l}0,16 \pm \\
0,02\end{array}$ & $\begin{array}{l}0,31 \pm \\
0,02\end{array}$ \\
\hline $\begin{array}{l}2-2,4-Д А \\
n=20\end{array}$ & $\begin{array}{l}0,78 \pm \\
0,05\end{array}$ & $\begin{array}{l}60,2 \pm \\
5,3\end{array}$ & $\begin{array}{l}0,79 \pm \\
0,14\end{array}$ & $\begin{array}{l}0,56 \pm \\
0,09\end{array}$ & $\begin{array}{l}0,19 \pm \\
0,04\end{array}$ & $\begin{array}{l}0,42 \pm \\
0,04\end{array}$ \\
\hline$P_{1-2}$ & 0,048 & 0,024 & 0,029 & 0,016 & 0,506 & 0,018 \\
\hline
\end{tabular}

Таблица 2. Влияние малых доз гербицида 2,4-дихлорфеноксиуксусной кислоты на интенсивность спонтанной и железоиндуцированной хемилюминесценции суммарной фракции апо-В сыворотки крови животных, $(\mathrm{M} \pm \mathrm{m})$

\begin{tabular}{|l|l|l|l|}
\hline $\begin{array}{l}\text { Группа } \\
\text { (n) }\end{array}$ & $\begin{array}{l}\text { Спонтанная светимость, } \\
\text { у.е. (СПС) }\end{array}$ & $\begin{array}{l}\text { Величина быстрой вспышки, у.е. } \\
\text { (h) }\end{array}$ & $\begin{array}{l}\text { Светосумма, } \\
\text { у.e. } \\
\text { (S) }\end{array}$ \\
\hline $\begin{array}{l}1-\text { Контроль } \\
(22)\end{array}$ & $0,19 \pm 0,05$ & $2,4 \pm 0,64$ & $6,9 \pm 1,2$ \\
\hline $\begin{array}{l}2-2,4-Д А \\
(20)\end{array}$ & $0,77 \pm 0,22$ & $6,1 \pm 1,4$ & $12,4 \pm 2,6$ \\
\hline$P_{1-2}$ & 0,014 & 0,021 & 0,062 \\
\hline
\end{tabular}

с использованием критерия Стьюдента, принимая критический уровень значимости $\mathrm{p}<0,05$.

\section{Результаты исслеАования}

Из материалов таблицы 1 следует, что длительное потребление животными воды, содержащей 2,4-ДА, приводило к увеличению содержания диеновых коньюгатов и малонового диальдегида в сыворотке крови на 20\% и 39\%, соотвественно, по сравнению с контролем.

Содержание продуктов перекисного окисления липидов - ДК и МДА в печени животных было на $72 \%$ и 75\%, соответственно, выше, чем у контрольных крыс.

Далее следует, из данных представленных в таблице 1, что в условиях поступления гербицида содержание ДК и МДА в сердечной мышце практически не изменилось, по сравнению с контролем.

Таким образом, результаты проведенных исследований показали, что длительное поступление с питьевой водой малых доз 2,4-ДА приводило к увеличению концентраций продуктов перекисного окисления липидов в сыворотке крови и в гомогенатах печени экспериментальных животных.
Поскольку одним из последствий активации ПОЛ в печени является изменение метаболизма липопротеинов крови, нами были определены основные показатели спонтанной и железоиндуцированной хемилюминесценции в атерогенной суммарной фракции апо-В, отражающие нарушения в их обмене [10, с. 25].

Как видно из таблицы 2, интенсивность хемилюминесценции суммарной фракции апо - В ЛП, выделенной из сыворотки крови животных, потреблявших с питьевой водой малые дозы гербицида 2,4-ДА, была достоверно выше, чем в группе животных, потреблявших бутилированную воду.

Так, спонтанная светимость в неиндуцированной $\mathrm{Fe}^{2+}$ суммарной фракции ЛПОНП И ЛПНП, выделенной из сыворотки крови животных, была в 4 раза выше в группе животных, получавших с питьевой водой малые дозы 2,4-ДА, относительно контроля.

После активации $\mathrm{Fe}^{2+}$ величина и длительность быстрой вспышки в этой же группе крыс в 2,5 раза превышала в группе, потреблявших бутилированную воду.

Интенсивность и длительность светосуммы медленной вспышки сыворотки крови крыс, потреблявших 
Таблица 3. Влияние малых доз гербицида 2,4-ДА на активность антиоксидантных ферментов у животных, $(\mathrm{M} \pm \mathrm{m})$

\begin{tabular}{|c|c|c|c|c|c|c|}
\hline \multirow[b]{2}{*}{ Группа, число крыс } & \multicolumn{2}{|c|}{ Лизат эритроцитов } & \multicolumn{2}{|l|}{ Печень } & \multicolumn{2}{|l|}{ Сердце } \\
\hline & $\begin{array}{l}\text { Каталаза, } \\
\text { мкмоль/мин/ } \\
\text { мг Нb }\end{array}$ & $\begin{array}{l}\text { СОД, } \\
\text { мкмоль/мин/мг } \\
\text { Нb }\end{array}$ & $\begin{array}{l}\text { Каталаза, } \\
\text { мкМ/ г белка }\end{array}$ & $\begin{array}{l}\text { СОД, } \\
\text { мкМ/ г } \\
\text { белка }\end{array}$ & $\begin{array}{l}\text { Каталаза, } \\
\text { мкМ/ г белка }\end{array}$ & $\begin{array}{l}\text { сод, } \\
\text { мкМ/ г } \\
\text { белка }\end{array}$ \\
\hline $\begin{array}{l}\text { 1- Контроль } \\
\mathrm{n}=22\end{array}$ & $\begin{array}{l}0,41 \pm \\
0,04\end{array}$ & $\begin{array}{l}241,5 \pm \\
28,1\end{array}$ & $\begin{array}{l}1,83 \pm \\
0,13\end{array}$ & $\begin{array}{l}150,1 \pm \\
10,0\end{array}$ & $\begin{array}{l}3,1 \pm \\
0,29\end{array}$ & $\begin{array}{l}16,2 \pm \\
1,9\end{array}$ \\
\hline $\begin{array}{l}2-2,4-Д А \\
n=20\end{array}$ & $\begin{array}{l}0,22 \pm \\
0,03\end{array}$ & $\begin{array}{l}157,7 \pm \\
23,2\end{array}$ & $\begin{array}{l}1,06 \pm \\
0,09\end{array}$ & $\begin{array}{l}123,0 \pm \\
8,1\end{array}$ & $\begin{array}{l}2,3 \pm \\
0,17\end{array}$ & $\begin{array}{l}22,1 \pm \\
2,2\end{array}$ \\
\hline$P_{1-2}$ & 0,005 & 0,027 & 0,001 & 0,042 & 0,022 & 0,049 \\
\hline
\end{tabular}

Таблица 4. Влияние малых доз гербицида 2,4-ДА на интенсивность спонтанной и железоиндуцированной хемилюминесценции фракции липопротеинов высокой плотности сыворотки крови животных, $(\mathrm{M} \pm \mathrm{m})$

\begin{tabular}{|l|l|l|l|l|}
\hline $\begin{array}{l}\text { Группа } \\
\text { (n) }\end{array}$ & $\begin{array}{l}\text { Спонтанная } \\
\text { светимость, у.e. } \\
\text { (СПC) }\end{array}$ & $\begin{array}{l}\text { Величина быстрой } \\
\text { вспышки, у.е. } \\
\text { (h) }\end{array}$ & $\begin{array}{l}\text { Светосумма, } \\
\text { у.е. } \\
\text { (S) }\end{array}$ & $\begin{array}{l}\% \\
\text { Подавления }\end{array}$ \\
\hline $\begin{array}{l}1-\text { Контроль } \\
(22)\end{array}$ & $0,3 \pm 0,06$ & $0,70 \pm 0,07$ & $137 \pm 7,4$ & $29,20 \pm 0,72$ \\
\hline $\begin{array}{l}2-2,4-Д А ~ \\
(20)\end{array}$ & $0,32 \pm 0,04$ & $0,83 \pm 0,04$ & $350 \pm 13,4$ & $15,34 \pm 1,10$ \\
\hline$P_{1-2}$ & 0,783 & 0,115 & 0,001 & 0,001 \\
\hline
\end{tabular}

с питьевой водой нетоксичные дозы гербицида 2,4-ДА, была почти в 2 раза выше, чем этого же показателя суммарной фракции апо - В ЛП сыворотки крови животных, получавших бутилированную воду.

Таким образом, результаты спонтанной и железоиндуцированной хемилюминесценции суммарной фракции апо-В показали более высокую интенсивность процессов СРО в суммарной фракции апо-В, выделенной из сыворотки животных, получавших с питьевой водой малые дозы 2,4-ДА.

Одним из важных звеньев в формировании окислительного стресса является снижение мощности антиоксидантных ферментов защиты организма (каталазы и супероксиддисмутазы) [11, с. 4790].

В связи с этим, нами было оценено влияние малых доз гербицида 2,4-ДА на активность антиоксидантных ферментов. В таблице 3 представлены данные, отражающие состояние антиоксидантной системы защиты у контрольных и опытных животных.

Из материалов таблицы следует, что длительное потребление животными воды, содержащей 2,4-ДА, приводило к снижению активности каталазы и суперок- сиддисмутазы в эритроцитах животных на 46\% и 35\%, соответственно.

Состояние активности антиоксидантных ферментов в печени характеризовалось понижением активности каталазы и СОД на $42 \%$ и 18\%, соответственно у животных, получавших 2,4-ДА, по сравнению с контролем.

Изменение активности антиокислительных ферментов в гомогенатах сердца носили разнонаправленный характер и заключались в снижении активности каталазы в 1,3 раза и увеличении активности супероксиддисмутазы на $36 \%$, от контрольного уровня.

Снижение антиоксидантных механизмов проявляется также в способности ограничивать интенсивность спонтанной и железоиндуцированной хемилюминесценции в модельной системе фосфолипидов.

Данные, представленные в таблице 4, отражают способность липопротеинов высокой плотности (ЛПВП) снижать интенсивность ПОЛ у животных в условиях поступления с питьевой водой 2,4-ДА.

Так как в основе субстрата используется модельная система фосфолипидов, сходных с липидами крови, ме- 
тодика не предполагает видимых различий между спонтанной светимостью для контрольной и опытной групп.

У животных, получавших с питьевой водой малые дозы 2,4-ДА, величина быстрой вспышки была на 19\% больше, чем в контроле.

Величина светосуммы медленной вспышки фракции ЛПВП, выделенной из сыворотки крови животных, получавших с питьевой водой 2,4-ДА в концентрации ниже ПДК, была в 2,6 раза выше, чем величина исследуемого параметра в контроле.

Антиатерогенную направленность ЛП спектра характеризует способность ЛПВП снижать интенсивность СРО при добавлении их к стандартной системе, содержащей фосфолипиды, и оценивается через процент подавления СРО в стандартной хемилюминесцентной системе (СХC).

Видно, что у животных в условиях поступления с питьевой водой малых доз 2,4-ДА, процент подавления СРО в стандартной хемилюминесцентной системе был на $48 \%$ ниже, по сравнению с контролем.

Таким образом, в группе животных, получавших с питьевой водой малые дозы 2,4-ДА, отмечено снижение способности ЛПВП подавлять СРО в стандартной хемилюминесцентной системе, относительно интактных животных.

\section{Обсужление}

Наиболее существенным фактом, установленным в результате проведенного исследования, является то, что под влиянием невысоких концентраций 2,4-ДА, поступающего с питьевой водой, происходит активация процессов свободно-радикального окисления и снижение мощности ферментов системы антиоксидантной защиты, проявляющееся накоплением продуктов перекисного окисления липидов и увеличением пероксидации различных фракций липопротеинов, которые могут приводить к ряду последствий, неблагоприятных для организма в целом [14, с. 851]. Таким образом, есть основание думать, что поступление с питьевой водой малых доз данного гербицида, может приводить к широкому спектру заболеваний, в развитии которых важная роль принадлежит окислительному стрессу. На наш взгляд повсеместная распространенность гербицида 2,4-ДА определяет актуальность весьма трудоемкой задачи его идентификации и проведении мероприятий по защите источников питьевого водоснабжения от загрязнения данным поллютантом [4, c. $8 ; 3$, c. 567].

\section{КонфАикт интересов}

Авторы данной статьи сообщают об отсутствии конфликта интересов.

\section{ЛИТЕРАТУРА}

1. Государственный доклад «0 состоянии и 06 охране окружающей среды Российской Федерации в 2017 году». [Электронный ресурс] — URL: http://www. mnr.gov.ru/docs/gosudarstvennye_doklady/.—- (дата обращения 17.09.2019).

2. Лопухин, Ю.М. Регистрация хемилюминесценции составных частей сыворотки крови в присутствии двухвалентного железа // Бюлл. Эксп. Биол.1983.- - Т. 95, № 2.-C. 61-63.

3. Ракитский, В.Н.Оценка и управлением риском при различных технологиях применения пестицидов / В.Н. Ракитский, Н.Е. Федорова, И.В.Березняк, А.В.Ильницкая // Актуальные вопросы анализа риска при обеспечении санитарно-эпидемиологического благополучия населения и защиты прав потребителей: материалы IX Всероссийской научно-практической конференции с международным участием.- Пермь, 2019.C. 565-570.

4. Рахманин, Ю.А. Актуализация методологических проблем регламентирования химического загрязнения и изучения его влияния на качество жизни и здоровье населения. Сб.: Методологические проблемы изучения, оценки и регламентирования химического загрязнения окружающей среды и его влияние на здоровье населения. Материалы Пленума Научного совета РФ по экологии человека и гигиене окружающей среды, под редакцией академика РАН Ю. А. Рахманина. - 2015.-С. 3-11.

5. Сирота, Т. В. Новый подход в исследовании процесса аутоокисления адреналина и использование его для измерения активности супероксиддисмутазы / Т. В. Сирота // Вопр. мед. химии. — 1999.— - Т. 45, № 3.— С. 263-272.

6. Фархутдинов, Р.Р., Лиховских В. А. Хемилюминесцентные методы исследования свободно-радикального окисления в биологии и медицине.—Уфа: БГмУ, 1995.- - 90c.

7. Фархутдинов, Р. Р. Исследование хемилюминесценции биологического материала и оценка антиокислительной активности на приборе ХЛМ-003: методические рекомендации / Р. Р. Фархутдинов.-Уфа, 2005.-24 с.

8. A rare case of 2,4-Dichlorphenoxyacetic acid (2, 4-D) poisoning / Singla Sanjay [et al.] // International Journal of Contemporary Pediatrics- 2017.— Vol.4, № 4. — P. $1532-1533$.

9. Burns, C. J. Review of 2,4-dichlorophenoxyacetic acid (2,4-D) biomonitoring and epidemiology / C. J. Burns, G. M. Swaen // Critical Reviews in Toxicology.2012.—Vol.42, № 9. 一 P. 768-786.

10. Dai, Y. Scavenger receptors and non-coding RNAs: relevance in atherogenesis / Y. Dai [et al.] // Cardiovascular Research.— 2016.—Vol. 109, № 1.—P. 24-33. 
11. 2,4-Dichlorophenoxyacetic acid promotes S-nitrosylation and oxidation of actin affecting cytoskeleton and peroxisomal dynamics / M. Rodríguez-Serrano [et al.] // Toxicology Letters. - 2014. - Vol.65.-P. 4783-4793.

12. Gangemi, S. Occupational exposure to pesticides as a possible risk factor for the development of chronic diseases in humans (Review)/S. Gangemi [et al] // Molecular Medicine Reports. - 2016. — Vol.14, № 5.—P. 4475-4488.

13. Heindel, J. J. Metabolism disrupting chemicals and metabolic disorders / J. J. Heindel [et al.] // Reproductive Toxicology. — 2017. — Vol. 68. — P. 3-33.

14. Hung, Y.C. Cholesterol loading augments oxidative stress in macrophages/Y. C. Hung [et al.] //Elsevier.— 2006.— Vol. 580, № 3.—P. 849-861.

15. Kim, H. J. Exposure to pesticides and the associated human health effects/ H. J. Kim [et al.] // Science of The Total Environment- 2017.— Vol. 575, № 1.— P.525535.

16. Li, X. F. Drinking water disinfection byproducts (DBPs) and human health effects: multidisciplinary challenges and opportunities / X. F. Li, W. A. Mitch // Environmental Science \& Technology. - 2018. - Vol. 52. - P. 1681-1689.

17. Ohkawa, H. O. Assay for lipid peroxides in animal tissues by thiobarbituric acid reaction / H. 0. Ohkawa [et al.] // Anal.Biochem. — 1979. — Vol. 95, № 2.—P. 351358.

18. Placer, Z. Lipperoxidation systeme im biologischen material // Nahrung. 1968. Bd. 12. S. 679.

19. Zuck, H. In Methods of enzymatic analysis / H. Zuck // Ed by Bergmeger H. — Oxford: Pergamon Press, 1963. — P. 885-894.

(с Красиков Сергей Иванович ( ks_oren@mail.ru ), Боев Михаил Викторович ( boevm@inbox.ru ),

Шарапова Наталия Васильевна ( natalya.sharapova2010@yandex.ru ), Карманова Дарья Сергеевна ( daryakarmanova@mail.ru ).

Журнал «Современная наука: актуальные проблемы теории и практики»

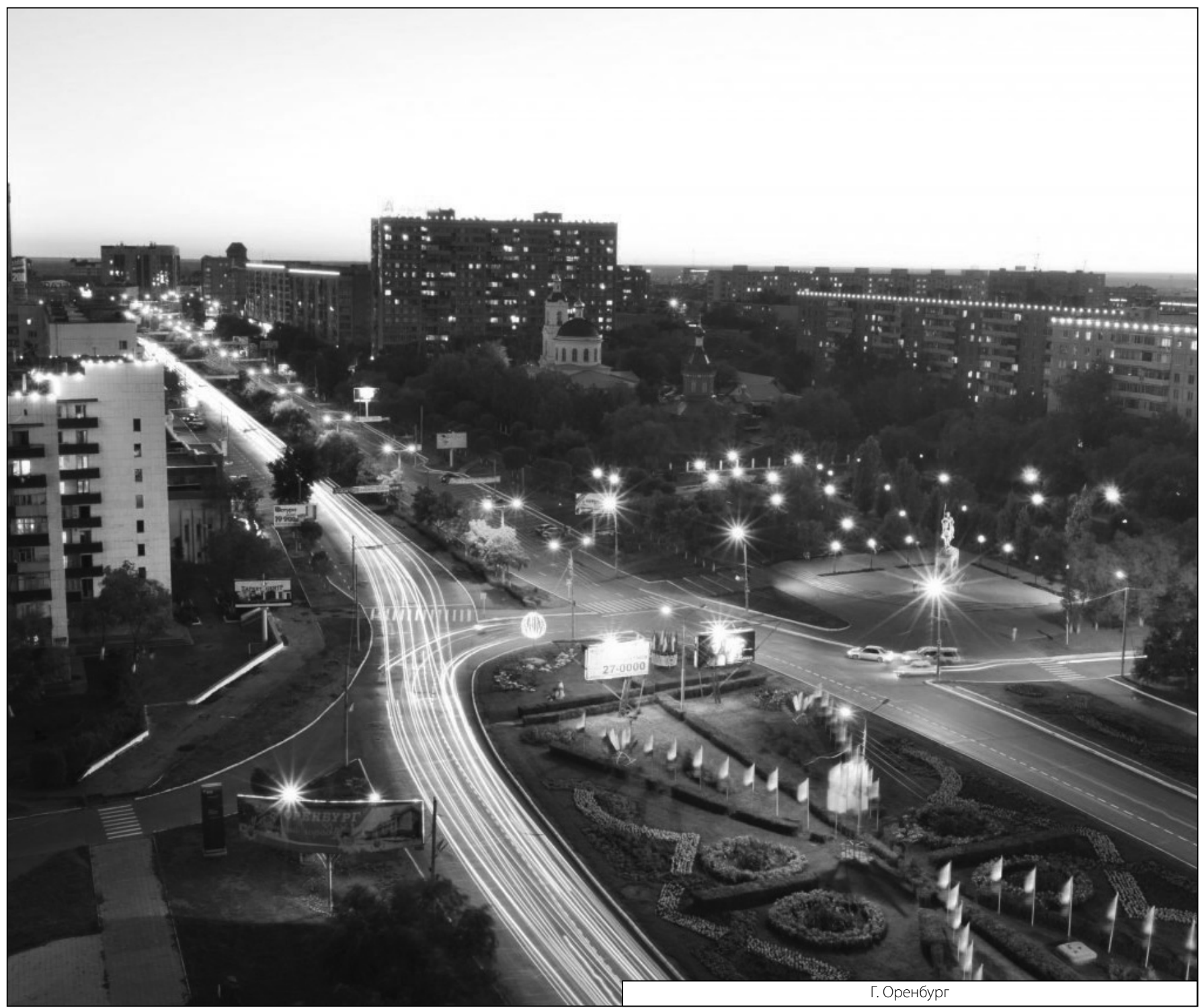

